\title{
A STUDY OF THE BLOOD IN GENERAL PARALYSIS.'
}

\author{
By Joseph A. Capp8, A.B., M.D.,

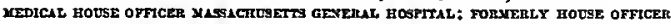 \\ MCLEAY HOSTTAL.
}

Snce attention has been given to the study of the blood in general a number of observers have written npon the blood in the insane; and more particularly is tbis true witb reference to general paralysis, partly because of its frequency and partly because tbe diagnosis can be made with greater definiteness in this tban in most other forms of mental disease.

As early as 1846 Erlenmeyer made investigations upon the globules and fibrin of the blood in the insane, fanding an increase in eitber to be rare.

Hittorf, in 1847 , also arrived at the conclusion that in mania there is a diminution in the number of red globules and fbrin, and that the blood is in a watery condition.

To Michea' (1818) belongs the credit of having first studied the blood in general paralysis, in which be noted an increase in the globules. He also speaks of a change in the character of the blood in convulsions and cataleptic seizures, though what this change is ho does not say.

Sutherland' (1873) considered a grent increase in the white cells and an absence of rouleaur-forming powrer as an indication of low vitality with a grave prognosis. He found a lencocytosis in the insane generally, hut most marked in general paralysis.

The conclusions of Voisin' (1879) on the condition of the blood in general paralysis are more interesting bistorically than of actual value. He states that tbe blood of general paralytics spreads on a cover-glass with less pressure tban normal blood; that the red cells make peculiar rouleaux with wbite corpuscles between them; tbat tbe coagulability is greater ; that in the last stages in some cases vibrions and bacteria appear.

MacPhail (1884), in his valuable contribution on the blood of general paralytics, studied the subject more thoroughly and with better apparatus tban any of bis predecessors. In fifteen cases examined be found the hæmoglohin lorr on admission, bigber in the quiescent period, and

\footnotetext{
1 From work done in the laboratory of Ire Len Eospltal nader the supervision of nr. Bdward Cowles.

2 Quoted hy Dagonet, in Traite des Maladles Mentales, 1894, p. 103.

3 Quoted in Bucknill and Tuke's Prycholog. Bredielne, ath ed., p. 597.

- Recherehes clinfques gar le gang daaj les nevroses. Rer. In Zeitschrift fur Psychlat., vol. 7. $\mathrm{P} .485$.

" "On the Histology of Blood In the Inssne." Journsl of Ment Sclen., vol. xixl. p. 147.

- Paralsde General des Allenes, 1879. p. 160.

" "Clinical Observation of Blood in the Insune" Jotrr. of 3fent. Sclen., rol. IIx. p. s78.
} 
low again during the paralytic stage. The red corpuscles "deteriorat s" in quantity and quality coincident with the progress of the disease; "small granule-cells" are not present in the last stage; the relative proportion of white to red corpuscles is increased, and this increase is like. wise coincident with the progress of the disesse.

Lewis' (1889) ohserved practically the same condition in a series of cases of general paralysis, namely, a reduction in the hremoglohin nnd number of red corpuscles and an increase in the white. In 7 of 21 cases, how-. over, the white count was 10,000 or under, while in a few the leucocytosis was very marked.

Smyth" (1890), in his analysis of 40 cases, states that the hamoglohin in general paralysis is within physiological limits, though it may he very high in the exalted stage of the disease. There was much less falling off in the red corpuscles than in other forms of insanity. The specific gravity he found increased.

D'Ahundos (1891) has experimented upon the toxicity of the hlood in the insane, and has demonstrated that the hlood of general paralytics injected into animals is more toxic than normal hlood.

According to Winckler, the hæmoglohin and red corpuscles in general paralysis vary with the body-weight, the hremoglobin, however, diminishing more than the red cells. They hoth decrease in the early stage, are stationary in the so-called second stage, and fall agnin in the third. He noticed, along with a fall in hody-weight, that a paralytic attack has a deteriorating influence on the hlood.

Agostinis has investigated the "ieotonia" of the hlood, or the power of resistance of the glohules to solution. In typical general paralysis the isotonia is little altered, and the hremoglohin and red cells usually normal, while all are diminished in periods of long excitement. During apoplectiform attacks the isotonis is reduced, with hut little change in the hremoglohin or red cor puscles.

The earliest attempt to study the variety of leucocytes was made hy Krypiakiewicz, who devoted his attention to the eosinophileg. He ohserved no increase in these cells in any case or in any stage of the disease. The variation in the eosinophiles was hetween 1 and 5 per cent., and was without relation to any peculiarity, course, or stage of the disease; they never entirely disappear from the hlood. In some cases the leucocytes were sufficiently increased to justify the name of leucocytosis.

1 Textrbook of sental Diseases, p. 257.

Joumal of Jental Seience, rol. xxxr. p. 504.

" "Sull' axione tosica e buttericlde del slero di sangue del Pazel." Ririst. speriment. di Freniatria, vol. xvil. F. 17. and rot. Ivill. F. 2, p. 322.

" "Uber Elntuntersuchungen bel Geisteskrankea," Inang. Dlssert, 189,, Bonn, p. 39.

" "Bulla Isotonta del angue negu allenat." Rivist, sperdm. vol. xvili. F. $\$$ and 4, p. 492

- Einige Beobachtungen nber das Blnt der Gelstestranken. Wien. mediz. Wochensehrift, Nr. 25, 1892. 
The hæmoglohin and red corpuscles were diminished, and there was poikilocytosis.

Zappert' (1892) reports two cases of general paralysis in which the red corpuscles were decressed, the leucocytes normal, and the eosinophiles slightly below the normal number.

Excitement and motor restlessness in general paralysis were found hy Vorster to cause a lowering of the specific gravity and hæmoglohin. Sometimes after paralytic attacks an increase in specific gravity and hremoglohin was ohserved, hut following light attacks no change took place. These alterations had no relation to the temperature.

Houston" gives the result of the hlood-examination in four cases of general paralysis; in all the hæmoglohin and red corpuscles were helow normal. The white corpuscles he considered, without counting them, ahout normal.

Roncoroni, in his study of the leucocytes in general paralysis, was concerned only with the eosinophiles. These he found to vary, at times very scarce, rarely in normal frequency, in extremely agitated cases with a tendency to violence they incresse from 8 to 18 per cent., and, in one instance, even to 25 per cent. of the total number of leucocytes.

Mire recently Burtons has puhlished his results in four cases of general paralysis. The red corpuscles averaged $5,177,500$, the white 10,250 , and the hxmoglohin 73 per cent. The differential counts are of little value, no percentages being given.

From the foregoing we see that all observers are almost unanimots in finding the red corpuscles and hæmoglobin either normal or decreased, except in excitement or after a paralytio attack. The specific gravity has been investigated hy only two men, one of whom claims that it is nlways high in general paralysis; the other, that it hecomes so after some paralytic attacks. By all who accurately cotsuted the white corpuscles an increase was noted except by Zappert, who made hut two observations, and Burton, who made four; both fotsnd the numher ahotst normal. Very little has heen done in making differential counts of stained specimens, since Krypiakiewicz, Zappert, and Roncoroni were only interested in the easinophiles, and Burton gives no figures whatever.

1 " tber das Vorkommen der cosinophllen zellen In menschttchen Blut." Zeitschrif far klln. Sfedicln., Bd. xrif. H. 3 and 4 .

s "Uber d. Hæmoglohingehalt n. d. spec. Gewlcht des Bintes bel Geisteskrank." Allgemeine

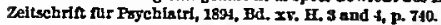

3 "On the Eramlanation of Blood in the Jnsape" Bost. Jred. and Barg. Journ., Jen. 18, 189.

1" Stndi mil leucocitl nel Pazzl." Archir dl Pslchiat, Sclenze. etc., 1894, vol.rv. F.iti. p. 293.

- "The Blood in the Insane." Am. Jonrn, of Insanity, 1895, vol. li. p. 435. We cannot re. frain from critlelsing the inacenracr of atatement In thls article. e. g.. the classlfication of 15mphoestes and large mononuclear cells under the head of neatrophiles; the statement that the lencocstes are " markedly decreased "In general paralysis, when his average was 10,250 and in po case fell below 9000 : the statement that no monontuclear celis were present in one case, the lllustration of whlch plalnly shows several of both large and small varietles. 
In the light of these facts it seemed very desirahle to examine the blood in all these particulars at the same time; and not only once in each case, hut to follow each through the various phases of the disease over as long a period as possible, to see what changes, if any, take place, and wbether the presence of certain mental and physical symptoms is attended by any constant alteration in the blood.

Mfethods. To ohtain the blood the lobe of the ear was pricked with n fine-pointed lancet after the skin had heen cleansed with alcohol. The corpuscles were counted with the Thoma-Zeiss npparatus, Toison's solution being used to stain the white corpuscles in a dilution of 1 to 100 . For estimating the red corpuscles, with hut few exceptions, 50 squares were counted in never less than tbree drops, or 150 squares in all. The whole ruled area was counted for leucocytes in four different drops, except in four instances, frequently in more when there was much disparity hetweeu the several results. Considerable time was saved by employing two or three counters.

The bremoglohin wns taken with Fleiscbl's hxmometer, and the average of four readioga obtained in eacb case.

For determining the specific gravity, Hammerschlag' ${ }^{1}$ metbod was used of suspending a blood-drop in the middle of a cylinder containing a mixture of benzol and cbloroform, the specifio weight of this mixture being that of the blood.

Cover-glass preparations were then dried for several hours in a tbermostat at a temperature of $100^{\circ} \mathrm{C}$. and stained with Ebrlioh's triple stain, as modified by Gollasch and Biondi, and a differential count mado of 1000 leucocytes in nearly every instance.

The absolute number in a cubic millimetre wag calculated for the sake of clearness. A Leitz mechanical stage was found to be of great cunvenience and value in traversing $n$ large area witbout recounting any field as well as for locating cells for future reference. The lens was a Zeiss $1 / 12^{\prime \prime}$ oil immersion with n No. 6 compensating ocular.

The classification is essentially that of Ehrlich.

1. Lymphocytes, as large or somewhat larger than the red corpuscles, with a round, deeply stained nucleus almost filliog the cell-hody.

2. Large mononuclear leucocytes, of greater size, with a large nucleus faintly stained. The protoplasm is more abundant tban in the lymphocytes, and is without granulations.

3. Transitional ${ }^{2}$ forms, including tbose cells which in tbe evolution of tbe large mononuclear into the nentrophile cells with polymorphous

1 Described by von Limbeck In Grundriss einer Klin. Path. des Blntes, 1892, p. 9.

3 Ehrlich's definition takes in all the large mononuciear forms with indented nuclei withont reference to the affinity of the protoplasm for coloring-matter. Ouskow lays more stress on the color of the protoplasin. (See review hy Thayer, Johus Hoplins Hosp. Reports, 1894, vol. Iv. No. 1, p.102.) 
nuclei, have nót only irregularly shaped nuclei, hut some evidence of beginning granulation in the protoplasm.

4. Polymorphonuclear neutrophiles (polynuclear neutrophiles), with nuclei of various shapes and having a protoplasm filled with neutrophilic granulations.

5. Eosinophiles, cells with polymorphous nuclei, hut containing large granulations staining with eosin or acid fuchsine.

Excluding those taken in cases with convulsions, nearly all the specimens of hlood were ohtained hetween 3 and 5 P.M., or from two and onehalf to four and one-half hours after dinner. The time of day is important, especially in its bearing upon digestion leucocytosis. Rieder ${ }^{2}$ states that after a proteid diet there is, in most persons, an increase in the white corpuscles, which reaches its maximum from three to four hours after eating, and on an average is ahout 33 per cent. ahove the normal count. Reinert's' conclusions are practically the same.

Nearly all the following examinations, therefore, were at a time when digestive leucocytosis is active. To ascertain what the physiological leucocytosis amounts to, and hy lesrning our own personal equation to have a hasis for comparison, hlood-specimens were ohtained from ten male adults in health at the aame length of time after eating. These persons were nurses and others living in the hospital, with diet similar to that of the patients.

From the tahle one can see that the red corpuscles and hremoglohin are ahout in the proportions commonly accepted. The normal specific gravity is not so well determined, variations depending on the method, age of individual, and probahly also on the time of day. Smyth, in the work referred to ahove, took as his normal 1056 , which is certainly much lower than most recent ohservers have found it in adult males. Hammerschlag obtained a range from 1056.5 to 1066 , with an average of 1060.5 Perhaps our result is made a little higher through the infuence of meals.

The average number of leucocytes is decidedly ahove the normal as given hy most authors, hnt not high considering the effect of digestion.

An important thing to ohserve in the differential count is that in spite of the wide variations in the number of leucocytes in these cases, the proportion of the cellular elements to each other does not change materially. In other words, in the leucocytosis following proteid digestion the relation of the polymorphonuclear to the mononuclear cells remains the same, a fact that distinguishes it from the inflammatory leucocytoses. The eosinophile cells, according to Rieder, ${ }^{3}$ tend to diminish in all leucocytoses, whether physiological or pathological.

1 Beltrbe zur Kentniss der Leukocytose, 1892, pp. 58 and 201.

- Dle Zhlung der Blatkorperchen, 1891, p. 35.

" Cited by Vlerordt in his " Daten nnd Tabellen," 1997, p. 126.

- Rleder, Beltro zar Kentniss der Len rocytase, IE92, p. 65.

5 Loc. dit, p. 65. 
CAPPS: THE HI,OOD IX GFSERAL PAIRALYSIS. 650

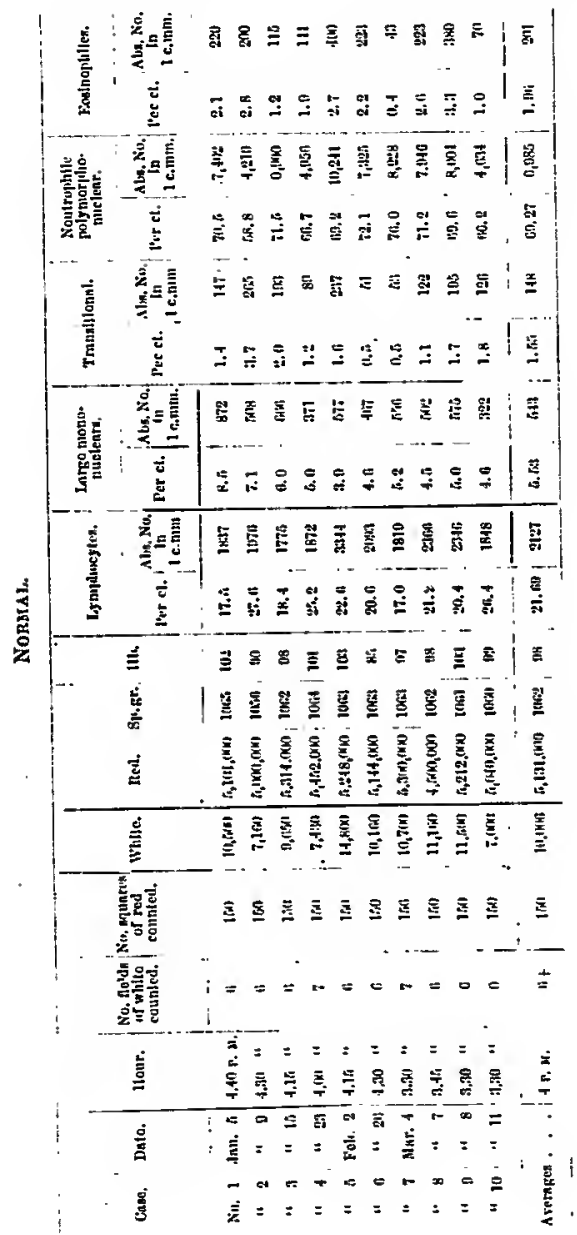


Throughout this paper the results in these healthy individuals will he taken as a hasis for comparison, since they were examined under as nearly as possihle the same conditions as the paralytics.

CASE I. S. E. S., aged thirty-five years, married, admitted Octoher, 1892. No heredity. Bince having influenza two years ago has heen vervous and irritahle. Has always overworked. Pupils unequal, talks slowly, tremor of tongue and hands, knee-jerks ahsent, Romberg's symptom, well-developed delusions of wealth, excited, unreasonahle, and extravagant. When the blood was first examined, ataria and dementia were very pronounced, and he was having convulsions at frequent intervals.

Upon studying the tahle it is evident that the red corpuscies are about normal and the specific gravity and hrmoglohin diminished. There is a leucocytosis amounting to 35 per cent. ahove the normal. The differential count shows that this lies cbiefly in the polymorphonuclear cells, the lymphocytes falling relatively and absolutely. The relative increase in the large mononuclears is greater than in any other element. No ahnormal variation is present in the eosinophiles. These examinations were made at a time sufficiently distant from convulaive seizures to he little if at all inflnenced by them, the nearest heing 14 hours after a light attack. During the nine months over which the examinations were made not much cbange in the hlood took place save a slight drop in the red corpuscles and specific gravity.

CAsE II.F. E. C., aged thirty fonr years, admitted in Octoher, 1892. Syplilis ten years ago. For several months previous to entrance made business blunders and was ahsent-minded. Impairment of moral sense, restless, and at times violent, extravagant ideas of grandear and power. Speech imperfect, staggering gait, writing faulty, knee-jerks increased. Later on he hecsme more paralyzed and demented, losing control of the voluntary muscles. At one time he had a convulaion. Died October 13, 1894 .

A general reduction in the red corpuscles, specific gravity, and hæmoglohin is apparent. The angmentation in the leucocytes is too slight to be considered abnormal. Aside from the increase in the polymorphonuclear neutrophile cells, the differential count reveals a low nnmber of lymphocytes.

Case III.-J. N., aged fify years, admitted Decemher, 1889. No heredity. Naturally of a nervous temperament. A change in character was first noticed eighteen months before entering the hospital. Memory poor. Grand ideas of his own greatress and importance. Delusions of wealth, emotional. Inequality of pupilg, fhrillary tremor of tongue, Romherg's symptom present, knee-jerk absent. Subsequently was suspicious, and acquired delusions and hallucinations of sight. Ataxia of gait and dementia. Died October 20, 1894. 
The red corpuscles are apparently little affected; the specific gravity and hæmoglohin are both suhnormal. The leucocytes are most interesting; with hut one deviation the number steadily rises as the termination of the disease draws near. This agrees in part with the conclusion of McPhail' that the increase in the white corpuscles is coincident with the progress of the affection, hut later ohservations fail to hear it out. With this progressive leucocy tosis the ahsolute number of the different varieties remains practically stationary excepting that of the polymorphonuclear cells, in which alone the increase takes place.

CASE IV.-C. C. B., eged forty-two year, married, admitted April, 1892. The onset was sudden. Three days ago hecame excited, talked loudly, and acted in an unusual manner, doing many senseless things. Has extravagant schemes. Pupils react sluggishly to light; tongue shows a fihrillary tremor; twitching of facial muscles; speech often hesitating, words heing repeated. Knee-jerks diminished. Romherg's symptom present. The physical and mental condition grew constantly worse, as manifested hy his unsteady walk and dementia.

This is a man in the demented stage who underwent comparatively little change in the nine months during which the hlood was taken, although the disease had progressed rapidly prior to this.

The hrmoglohin, always helow normal, was as high at the end as at the beginning. The specific gravity was not far from the normal and was quite constant. In the red corpuscles there is a considerable loss. The average of white corpuscles gives a gain of about 20 per cent. over the normal average, but the variation at different times has no especial relation to any state of mind or hody. In the differential count one notices a diminution in the lymphocytes and a rise in the large mononuclear and polymorphonnclear cells. The eosinophiles are within physiological limits.

CAsE V.-F. C., aged forty-three years, married, admitted Septemher, 1893. Dissipated in his youth. A year before admission he had an attack of speechlessness without loss of consciousness, which was followed hy others of a similar nature. For many months has heen irritahle and unreasonahle. Memory poor. Delusions. Hallucinations of hearing and sight. Fine tremor of tongue, slurring of syllahles, tremor of lips and facial muscles. Kuee-jerks ahsent. Romherg's symptom present. At times ataria of gait and mental confusion. April 22, 1895, died in an apoplectic seizure.

The red corpuscles are below the standard, and a tendency can be detected to decrease with the advance of the disease. Both the specific gravity and hamoglohin are diminished constantly. The leucocytes are slightly increased and do not fiuctuate in the course of the disesse to any extent except in one instance, where the leucocytosis reached 
18,000 . This unexpected result at once brought up the question of cause. Three days previous he had an apoplectic attack with subsequent paralysis of the face and inability to articulate, the temperature heing $104^{\circ}$. At the time of the hlood-examination the temperature had fallen to $100^{\circ}$. Had this marked increase in the leucocytes, specific gravity, and hxmoglohin any dependence on the seizure? A relation of cause and effect was more strongly suspected on finding, three days later, the hlood had recovered its usual condition, and with this clew further and more systematic examinations were made later on. In the production of the leucocytosis the polymorphonuclear neutrophiles and the lymphocytes hoth play an important part, hut the large mononuclear cells are relatively most increased. The average of the other counts shows only a little drop in. the lymphocytes and a rise in the number of large mononuclear cells.

CAse VI.-W. H. P., aged forty-nine years, admitted Fehruary. 1894. Overwork. For five years past his friends have noticed an unnatural nervousness and irritahility of temper. There is a history of a "fainting spell," for which he was in hed ssveral days. Delusions of wealth and grandeur, memory poor, sense of propriety impaired. Pupils do not react to light. Fibrillary tremor of tongue and muscles of the face. Articulation fanlty. Romberg's symptom, inco-ordination, ataxio gait. Knee.jerks absent.

Following the examinations over a period of eight months $w \theta$ find the specific gravity quite unchanging throughout, and a steady decrense in the hremoglobin and number of red corpuseles. The leucocytosis, always present, is sometimes very pronounced; at other times small. Unlike some of the precediog cases, the late counts were lower than the early ones. The absolute number of lymphocytes is nearly normal, that of the polymorphonuclear neutrophiles considerably increased, while the large mononuclears are more than douhled.

Case VII.-MI. W. C., aged forty-gix years, married, admitted March, 1894. Heredity in family. Syphilis twelve years ago. Has always overworked. Á bout two months since formed delusions of possessing a great fortune, was confused, and sometimes violent. Now more quiet and contented. Does not appreciate his condition or whereahouts. Pupils unequal. Knee-jerks much decreased. Romherg's symptom. Speech slow and hesitating, staxis of gait. Died January 6, 1895, after a hemiplegia followed hy convulsions that recurred frequently until his death.

The only noteworthy deviation from the normal is in the numbrr of white corpuscles, which are decidedly increased. This increase is entirely in the neutrophilic polymorphonuclear cells.

Case VIII.-A. F. S., aged thirty-two years, admitted July, 1894. Naturally a keen man, he hecame a year ago less attentive to husiness and gave it up. More recently wandered away from home in 
a state of mental confusion. Memory for recent events much impaired. Judgment and power of attention poor. Tremor of tongue and lips. Articulation decidedly defective. Knee-jerks increased. Marked ankleclonus, inco-ordination of movement.

This case is of interest because seen in the early stage, eoon after his entrance into the hospital. A general diminution in the red corpuscles, specific gravity, and hremoglohin is apparent. There is no leucocytosis; in fact, the count is helow the nverage normal The count of stained specimens is essentially a normal one.

Case IX.-J. M. R., aged forty-three years, married, admitted March, 1894. Syphilis eight years ago. For seven months has heen nervous and depressed. Afterward became exhilarated and developed delusions of wealth and grandeur. Moral sense apparently lost. Memory poor. Emotionnl. Tremor of tongue and lips. Speech hesitating. Romberg'e symptom. Knee-jerks diminished. Eandwriting characteristic with omisaions of letters and words. At the period when the latter ohservations were made he was hreaking down very rapidly.

We have here a good example of the general paralytic who runs a rapid course, the mental and physical impairment being more marked at each successive examination. The red corpuscles and hemoglohin show a tendency to decresse. In contrast to the previous cases the specific gravity is never helow the normal, and at times is extremely high. Speaking roughly, the epecific gravity is higher during periods of motor excitement than at other times, hut the correspondenco is neither constant nor accurate.

The leucocytosis is alwaye of fair proportions, and at one time even reached 20,000 . This was taken when the mental and physical disturhance had attained its climax, and the degree of excitement and confusion was more pronounced than at any other examination. The polymorphonuclear neutrophiles make up the greater part of the excess of leucocytes, hut relatively the large mononuclears increase much more, their actual number sometimes heing three times the normal. The lymphocytes are low throughout. At the heginning the eosinophiles were more numerous than afterward. It is worth mentioning that the eosinophiles were fowest when the leucocytosis was greatest.

Case X.-G. P. E., aged thirty-five years, admitted Fehruary, 1894. Syphilitic history questionahle. After a period in which he was irritahle and forgetful, he hecame excited and showed marked delusions ot grandeur. On admission, pupils unequal and facial tremor. Diminished suee-jerks. During the snhsequent year be progressed to profound dementis with great impairment in speech and gait.

A feature in the analysis of this case is the evenness of the various examinations, not only in the leucocytes, hut in the red corpuscles, hamoglohin, and specific gravity as vell. The last three are diminished, the white corpuscles ahove normal. Hit condition at the sereral times of ohservations was very similar except on Nóvemher 8 th, when he was voL. 111. Na. 6.-Juse. I896. 
declining with unusual rapidity. The leucocytes alone were affected, reaching 13,500 . In the differential count the lymphocytes, as usual, were ahnormal. The eosinophiles were at all times very high, hut with. out apparent relation to any phybical or mental condition.

Case XI_C. F., aged fifty years, admitted Mrarch, 1894. No ayphilis. Drank slcohol freely. Disesse hegan rather ahruptly with failure of memory and thickness of speech. This was soon followed ty unsteadiness of gait, delusions of grandeur, nnd excitement. Pupils unequal, react slightly to light. Fibrillary tremor of tongue and face. Kneejerk diminished. Steady progress during the year to high-grade dementia.

All the ohservations were made in the stage of contentment and physical well-being. The blood is quite normal, save a low percentage of hrmoglohin. The analysis of the whito corpuscles shows a fall in the lymphocytes with a great rise in the large mononuclear cells.

CASE XII.-A. G., aged forty years, admitted Novemher, 1894. No eyphilis. Violinist. For a nnmber of monthe hefore admission it was noticed that he was losing his skill in playing, that his apeech was affected, and that he was careless in keeping sppointmeita. Three weeks previous to entrance became extravagant and excited. Full of schemes. Tremor of tongue and face, slurring of speech, slight inequality of pupils and slow reaction to light. Sinco then has failed steadily in mind and hody, and has frequently heen very restless. Is demented and easily excited.

This palient was followed along from the excited stage st the heginning, with restlesaness and incessant talking, to the later period of quiet and contentment. No change in the hlood coincident with the alteration in the mental condition can be discovered aside from 8 fall in the homoglohin. The range of the specifio gravity is physiological and the red corpuseles likewise. A constant leucocytosis is present of fairly high grade, in which the lymphocytes and transitional cells are normal and the polymorphonuclears increased, hut much less relatively than the large mononuclears and eosinophiles, hoth of which in actual numbers are more than doubled.

Case XIIL-S. A. H, aged eixty yearg, admitted January, 1894. For a year previous to admission slight mental changes, slight tremor of face, and slight slowing of speech. Later hecame depressed and was brought to the hospital profoundly melancholy. There was marked tremor of face and tongue, increased knee-jerks, and Romherg's aymptom. With the depression some delnsions of grandeur - he is the "king of einners." $\mathrm{He}$ failed mentally and physically with extreme rapidity and died four weeks after admission.

Unfortunately, hut one specimen was obtained in this case, which was of auch short duration. When the hlood was taken three days hefore death, the patient was in hed with a temperature of $100.4^{\circ}$. The hlood is evidently concentrated since the specific gravity, bremoglohin, and red corpuscles are very high for a man pale and emaciated as he 
was. A distinct leucocytosis was found, consisting chiefly of polymorphonuclear neutrophile cells.

CASE XIV.-F. W., aged forty.four years, admitted January, 1894. History of ayphilis and excesses. Optic atrophy for eight years. For six months hefore admission, irritable, forgetful, and unmanageahle. On admission, confused, apprenhenaive, suspicious, hallucinations and delusione, emotional. Pupils unequal, reaction to light slow. Tremor of tongue, speech slurring, knee-jerks ahsent. One fainting attack in which he hecame very pale. In Septemher, restless and noisy, since then more quiet and happy, failing mentally. On April 1st had a small hedsore with slight discharge. April 12th, hedsore hesling, no discharge. May 1st, hedsore well.

The red corpuscles, hromoglohin, and specific gravity are all somewhat diminished, hut are not affected particularly at any period of the disease. The leucocytosis, though sometimes inconsiderahle, is fairly constant; it attains a maximum of 14,500 at a time when the patient had a small hedsore.

The differential count is remarkable in several respects. Previous to April 3d, the lymphocytes were diminished and the large mononuclear and eosinophile cells markedly increased. Upon this date, when the stained specimens were examined, the large mononuclears numbered four times the normal, and the eosinophiles more than ten times the normal. The patient was restless and noisy; on physical examination the only thing to be discovered was a hedsore the size of a five-cent piece, with a little discharge. Eleven days later when the abragion had cleaned up and was rapidly healing, another specimen was taken, Instead of a falling-off in the eosinophiles, they were still further increased, amounting to 2671 in a c.mm. Two weeks later, although the lesion had entirely healed, the easinophiles were still over five times the normal, the large mononuclears also remaining high. Such a grent number of eosinophiles is very unusual.

Excluding leukxmia ${ }^{1}$ and the results of injections ${ }^{2}$ of bacterial products, in hoth of which the ahsolute nnmher may he enormous, the highest counts of eosinophiles that we have heen ahle to find in a hurried review of the literature are as follows:

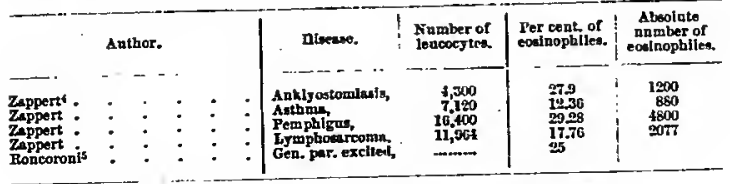

1 Von Limbeck: Grundriss einer kUn.Patologle des Bintes, p. 160.

2 Rleder: Loc. cit, p. 189.

- Zappert: Zeitschrift nur tiln. Medicin, Bd. xxill., Hent 3 and 4, p. 998.

- Loc. cik., pp. 257, 260, 271, and 250 .

- Archivo di Psichlatris, Sclenze Penele, ete, vol. xv. F. Hit. p. 293. 
Only in pemphigus and possibly the casa of general paralysis during excitement, in which the extent of the leucocytogis was not given, is the absolute numher greater than in this patient. To determine what effect, if any, a bedsora might have, two paralytics with open ahrasions on the huttocks wera examined :

\begin{tabular}{|c|c|c|c|c|c|c|c|}
\hline Case. & $\begin{array}{l}\text { Per ct. of } \\
\text { tympho- } \\
\text { eytes. }\end{array}$ & $\begin{array}{l}\text { Per cent of } \\
\text { large modo- } \\
\text { nuelear. }\end{array}$ & $\begin{array}{l}\text { Per cent. of } \\
\text { tranditlonni. }\end{array}$ & $\begin{array}{l}\text { Per cent, of } \\
\text { nentrophlle } \\
\text { polymorphe- } \\
\text { nueles. }\end{array}$ & $\begin{array}{l}\text { Per cent. of } \\
\text { eoinophilles. }\end{array}$ & $\begin{array}{c}\text { so. lonco- } \\
\text { cytten } \\
\text { engnted. }\end{array}$ & \\
\hline$A$ & 10.6 & 8.0 & 0.8 & 80.9 & 0.1 & 500 & Sore oyen, Lut \\
\hline $\mathbf{B}$ & $7.2^{\circ}$ & 6.4 & $n, n$ & sa.s? & 29 & 500 & $\begin{array}{l}\text { Slean. } \\
\text { dight purulent } \\
\text { dichare. }\end{array}$ \\
\hline. & - & . & & - & $\cdots \cdots$ & $\ldots$ & $--\cdot$ \\
\hline
\end{tabular}

The absence of any increase in the eosinophiles in these two cases indicates that prohahly tha hedsore was not the cause of their increase in the patient under discussion. Moreover, the maximum numher was present not during the activa stage, hut after it was nearly healed.

In view of these facts, it is fair to presume that this great augmentation of the eosinophiles has no dependence on the hedsore.

The mental condition of the patient was one of restlessness and irritability, hut without the excitement that existed in Roncoroni's case, which had 25 per cent. of eosinophiles.

CAsE XV.-J. F., aged forty-three years, admitted April, 1895. For two years before entrance a gradual failure of memory and intellect made evident by numerous husiness mistakes, hallncinations, and delusions, the latter changing frequently. Fe is considerahly demented, often confused, very forgetful; pupils unequal ; tremor of facial muscles; speech good, except for an occasional dropping of a word.

A diminution in the red corpuscles and hemoglohin is evident with a low degree of leucocytosis. The specific gravity is ahout normal. Tha large mononuclear cells sre rather high; otherwise there is no noteworthy alteration in the proportion of the various kinds of lancocytes.

CAsE XVI.-J. A. H, aged thirty-three years, admitted January, 1895. Successful husiness man, hard worker. No syphilis. A month prior to admission irritahle, extravagant, and reckless. On entrance, tremor of tongue, diminished knee-jerk. Romherg's symptom. Feels well. Exalted ideas of his ahility, delusions of wealth. Distinctly demented. Argyll-Rohertson pupil. Failed rather rapidly mentally and physically. At times much excited and emotional.

The case is of more value hecause the hlood was ohtained within three months of tha appearance of tha frat symptoms of general paralysis. The red corpuscles and hremoglohin were low, whila the specific gravity and white corpuscles are what ona vould expect in health. The lymphocytes are the only cells that give evidence of any alteration in 
the differential count. The highest nnmber of leucocytes was found during a period of ezcitement.

CAsE XVII.-F. D. M., aged thirty-one years, admitted July, 1888. A jear hefore this had a fainting attack with affection of speech. Delusions of persecution. Homicidal and auicidal. Dementia gradually came on. Speaks little. Constant stereotyped motor activity. Pupils unequal, tremor of facial muscles and tongue. Resistive. Speech very much impaired. Several convulsions.

April 21. Owing to a fall, has an abscess on elbow. Opened March 20tb. Wound healed. Mlind lately rather clearer. Much demented.

Standing out in contrast with the preceding case, the disease in this patient was of seven years' duration. A considerable leucocytosis characterizes the earliest examination, in which the large mononuclear element relatively plays the greatest part, though the polymorphonuclear increase is ahsolutely greater. The second specimen was taken after an abscess had formed near the elhow as a result of trauma. Tbe leucocytosis reached 20,330. The difference hetween tha inflammatory leucocytosis and tbat wbicb was present before the accident is the preponderance of the polymorpbonuclear element in the former. Tbe lympbocytes suffered an actual loss of numbers, while the eosinopbiles entirely disappeared. In tbis instance the chnracter of tbe differential count was sufficiently changed to make tbe diagnosis of pus extremely probable. - Wben tbe incigion bad entirely healed the count resumed in all essential respects its former proportions.

Case XVIII.-S. M. H., aged fifty-one years, admitted Decemher, 1894. Heard voices telling bim to kill himself and family, Violent and tbreatening. Frequent fainting spells for a year past. Tabes dorsalis for six years. Ptosis of left lid. Argyll. Rohertson pupil. Kneejerks absent on right, slight on left. Sensation diminisbed all over. Passes urine and feces involuntarily. Constantly grinds his teetb. Bentally dull and apathetic.

The leucocytosis on an average is 35 per cent. ahove the normal, hut does not vary much from tbe phyaiological proportion of cellular constituents excepting in an increased number of large mononuclear and a scarcity of eosinophile cells. The bighest leucocytosis corresponds to a time of restlessness and excitement.

CAsE XIX.-H. M., aged forty-two years, admitted July, 1894. History of syphilis(?) and overwork. For a year had been irritahle, and in the past month unusually emotional. Brought to hospital because he suddenly developed the most absurd husiness schemes on a large scale. Diminished knee-jerks, tremulous tongue, Argyll-Rohertson pupils. Incoherent, excited, destructive, and aggressive. Delusions of grandeur. Hore recently has heen quiet and contented, and it was during this period that examinations were made. 
664 CAPPS: THE BLOOD IX GEYERAL PARALYSIS.

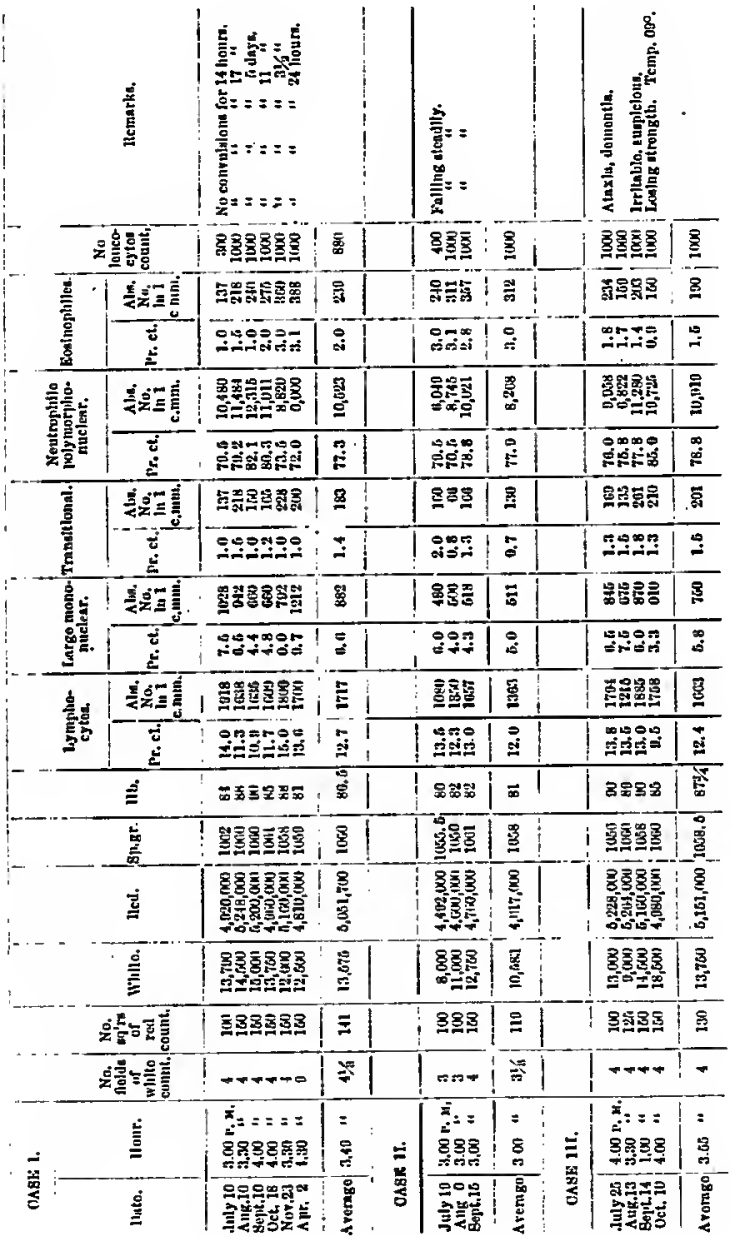


CAPPS: THE BLOOD IN GEXERAL PATALYSIS. 665

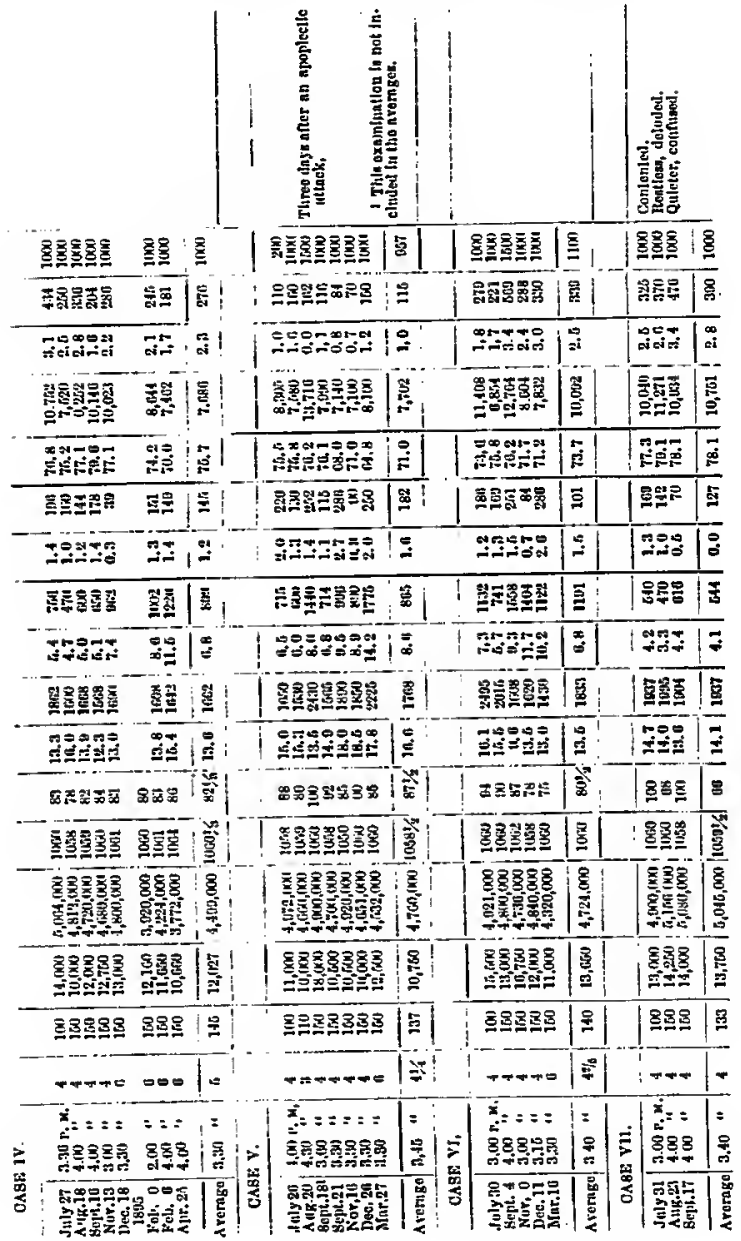




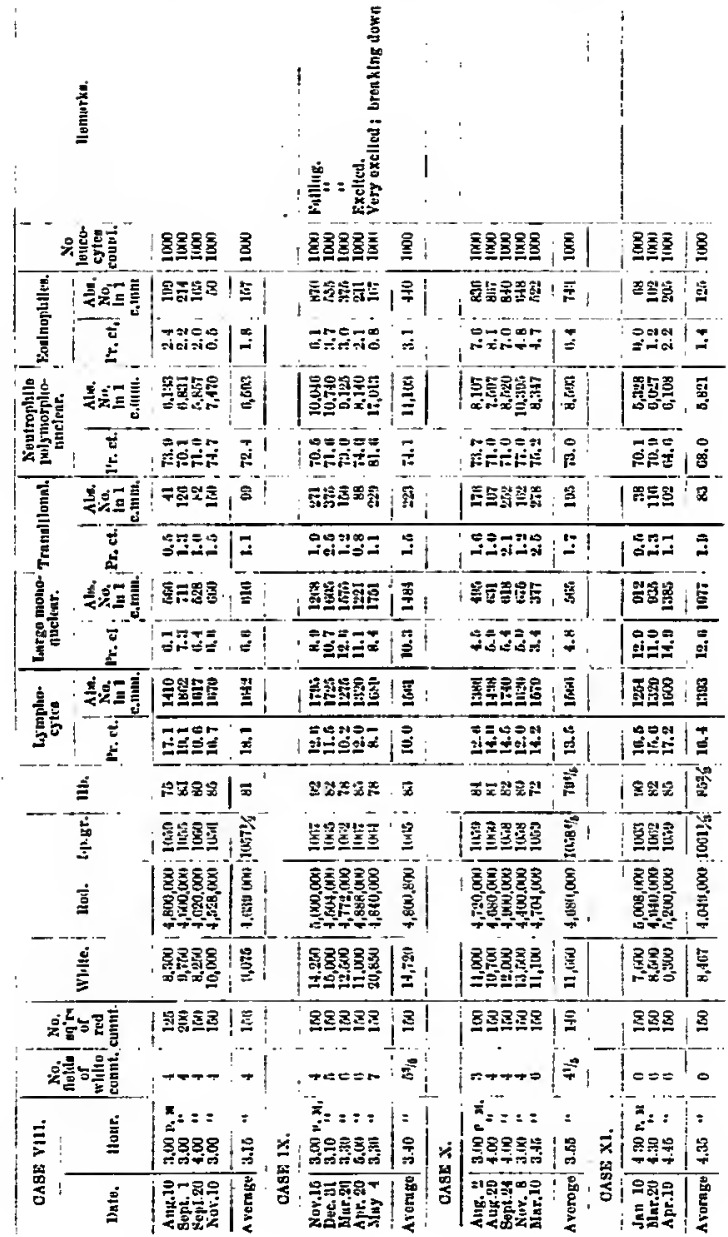


CAPPS: THE BIOOD IN GENERAI PARALYSIS. 667

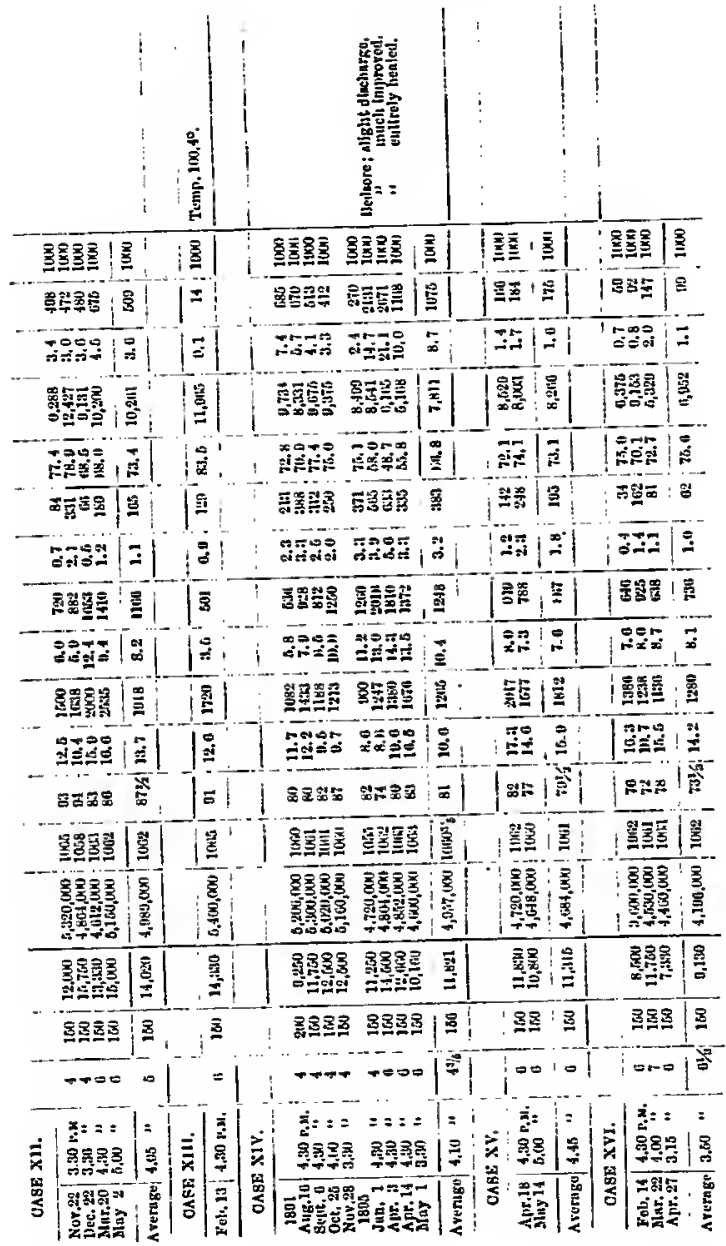




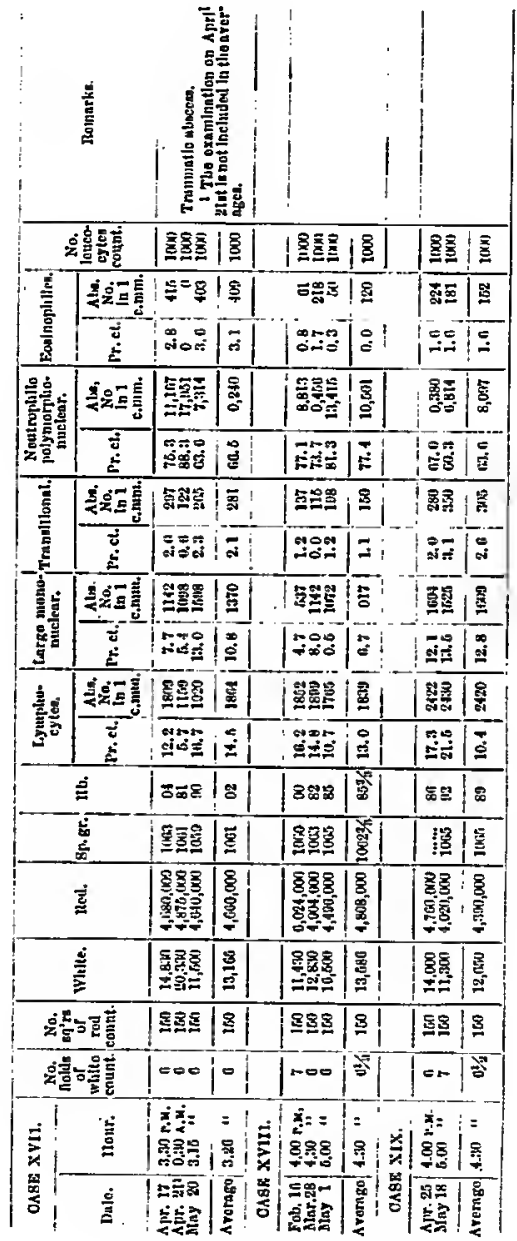


CAPPS: THE BLOOD IN GEXERAI PARALYSIS. 669

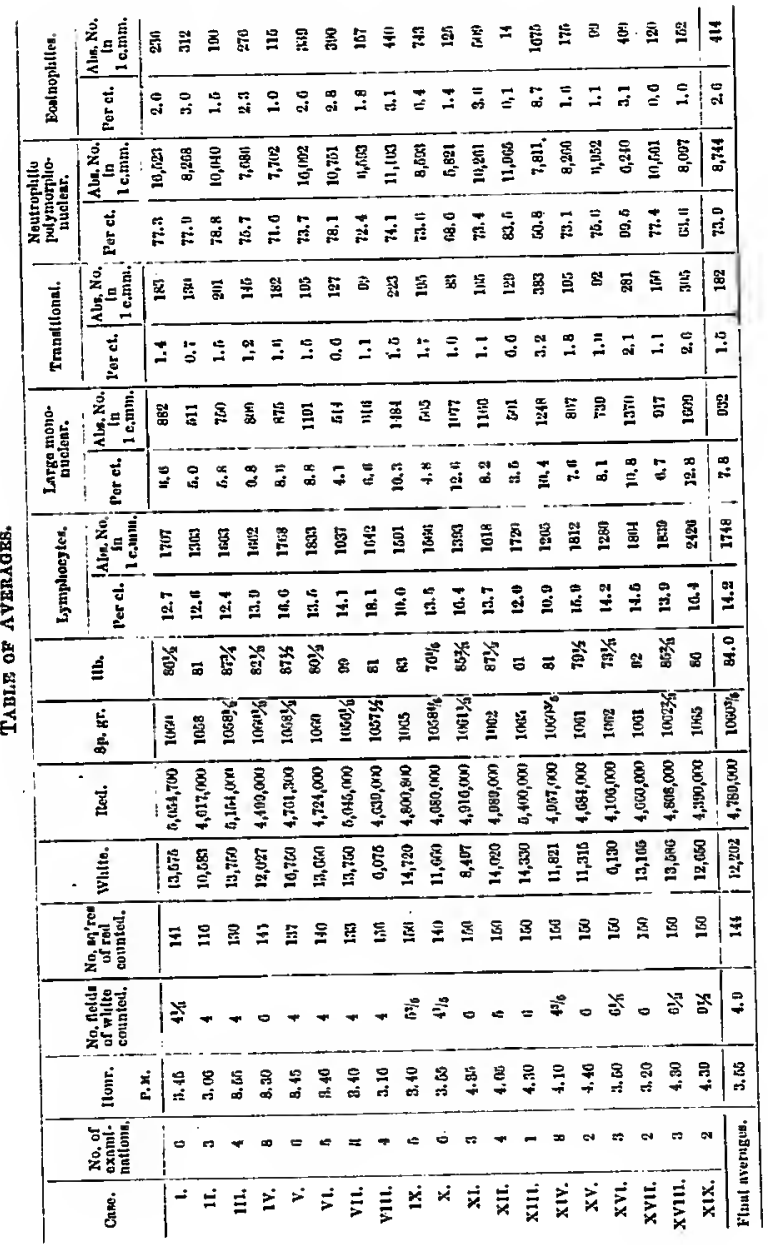


One sees a loss in the red corpnscles aud hremoglohin with a high specific gravity. The leucocytosis is different from most of the other cases. The number of lymphocytes is even ahove normal, and the large mononuclear and transitional cells are much more ahundant than normally.

Coscuusrove. In looking over the final tahle of averages we see that ab a whole the hxmoglohin in general paralysis ranges from 73 to 92 per cent., never falling below 70 per cent. The percentage is usually higher several months after entrance than on admisgion, which is prohahly due more to hospital care and ahundant good food than to any change in the disease.

The apecitic gravity varies from 1058 to 1066 , a difference that may he found in healthy individuals. The average falls somewhat helow the normal, hut the tendency is not pronounced enough to make it of any practical importance.

Much more constant is the diminished number of red corpuscles, which in only 4 cases reaches $5,000,000$. Nevertheless they maintain a much better average than some observers have stated.

The leucocytosis is never very great, hut considering that it is present in sone degree in the great majority of a large number of ohservations, we are led to helieve that in most cases of general paralysis there is a slight leucocytosis, antounting on an average to about 22 per cent. increase over the normal. Of three cases examined within four months of the heginning of the disease, two had no leucocytosis; a third, of longer duration and rapid in its progress, exhihited a decided increase in the white corpus. cles. From these few results it seems that early cases of gencral paralysis may have no leucocytosis volatever inless accompanied by excitement or running a rapid course. Nothing further can he eaid with regard to a correspondence hetween the degree of leucocytosis and the stage of the disease, since in many instances the leucocytes are more abundant in the earlier than in the later stages.

In the analysis of the leucocytes, the lymphocytes in every case hut one are found to fall helow the normal average. The large mononnclear cells, on the other hand, are generally increased, sometimes to three times the usual number. Roughly speaking, the nverage increase in the large mononuclears offeets the diminution in the lymphocytes, so that the total mononuclear element is little altered from the normal. The trau. sitional forms nearly always vary with the large mononuclears. The polynuclear cells as a rule vary directly with the leucocytosis, as with hut few exceptions they are the predominant variety.

The eosinophiles are more changeahle than any other form, varying from 14 to 1075 in a c.mm. They are inclined to be more plentiful in the cases that are restleas and show motor excitement, although sometimes the reverse is true. 
CAPPS: THE BLOOD IX GEYERAL PARALYSIS. 671

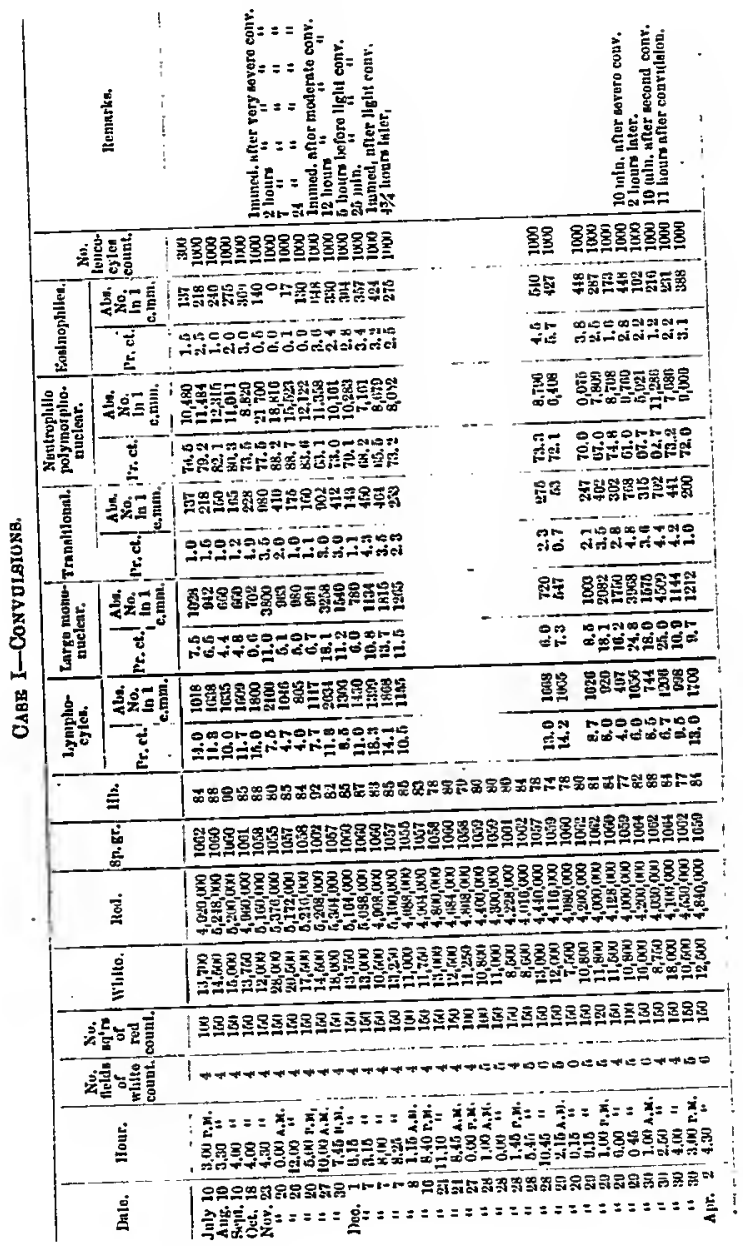


Costrubross asd Afoplectlooras Atraciza. Sereral times during the course of the examinations it was suspected that convulotions and apoplectic attacks might hare an inflnence on the blood. Accordingly,

Crane I.

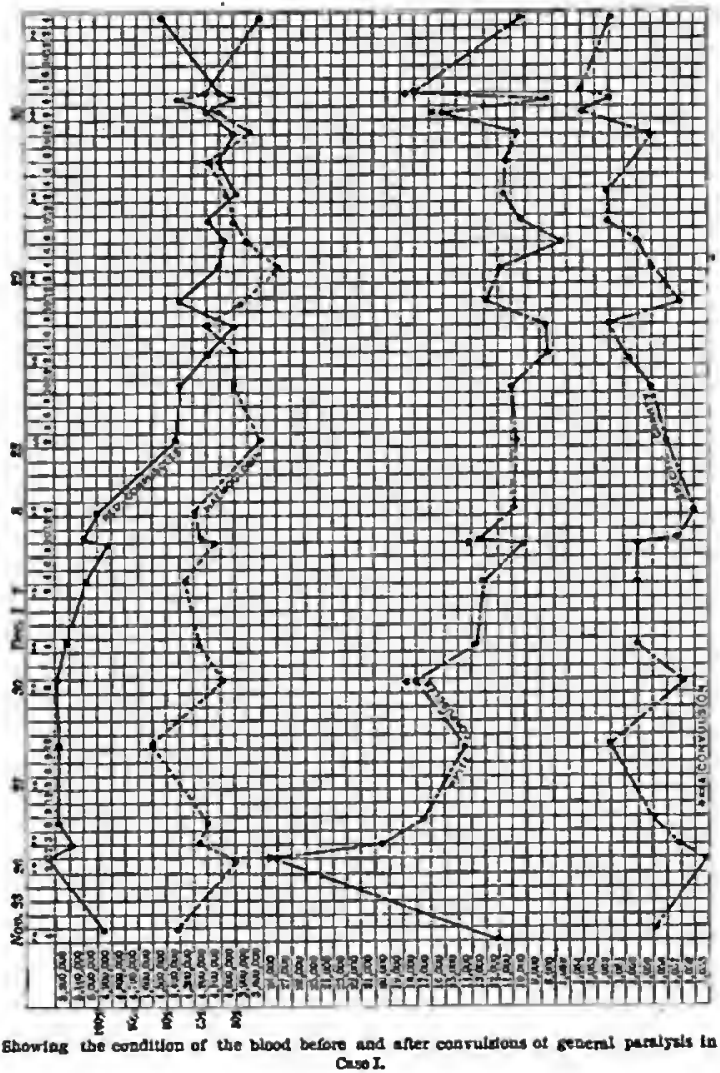




\section{Case I. (For history Case above.)}

The temperature was taken after every attack and was never above $99^{\circ}$.

It is evident in etudying this series of convulsions that the number of red corpuscles rises uniformly, if not greatly, at the occurrence of a seizure, and that it afterward diminishes as a rule.

The variation in the hremoglohin is perhaps too small to give it much importance, but in two of three cases it rose slightly and always remained high for some time later.

The lack of agreement at various times in the results on specific gravity does not justify any definite conclusion.

A glance at Chart I. showe a well-marked leucocytosis after Convulsions $\mathrm{L}$ and IL, lasting many hours. They do not indicate, however, whether this augmentation takes place gradually or euddenly. Twentyfive minutes before Convulsion III. the leucocyte count was 10,500, heing 13,500 afterward. This was a very light attack with but little increase. Precediog Convulsions IV. and V. the counts were low and rose abruptly at the seizure to 16,000 and 18,000 , respectively. None of these were preceded by any leucocytosis; although it was present immediately afterward. In general terma the degree of leucocytosis corresponded to the severity and duration of the fit, being highest after the most severe and very slight after a light convulsion. The effect of a series of attacks is apparently to intensify the leucocytosis, as the highest count was the fourth of a succession of convulaions. Moreover, No. V. is greater than No. IV., notwithstanding that they were of similar intensity and duration.

A tendency is noticeable for the leucocytes to fall even below their usual number before an attack. Two hours after No. IV. the white corpuscles were low, while usually the leucocytosis persists for several bours. The explanation may lie in the fact that it preceded by one hour a second seizure, which again produced a leucocytosis.

Twenty-four hours before the above-mentioned convulsion there was a distinct rise in the white as well as the red corpuscles. On this evening, a long deferred attack was expected and indicated by his actions. No muscular spasm, however, was seen at this time. One naturally wonders whether this might not have been an abortion of an nttack.

As would be expected, the polymorphonuclear element predominates, not, however, to the extent it does in the inflammatory leucocytoses; in fact, the increase is in the absolute connt rather than in the percentage. Just before each attack they diminish and eubsequently fall steadily. The role of the lymphocytes is peculiar. Previous to a convulsion, even many hours before, they decresse in number to become more numeroue again at the time of onset; even then tbe absolute count rarely reaches and never surpasses the normal. Followring the convulsion also they become subnormal again, and slowly recover their usual proportions. 
Most remarkahle of all is the action of the large mononuclears; unlike the polymorphonuclears their rise hegins hefore and rapidly progresses until the attack, when the maximum is attained. The count precerling a seizure on an average was douhle the normal, although there was as yet no increase in the leucocytes as a whole; the nu mber of large mononuclears just after the fit was over fonr times the normal, heing in one case nearly 4000 in a c.mm. Suhsequently they fell quite rapidly.

An interesting point is the inverse varistion hetween the lymphocytes and large mononuclears. In proportion as the latter increase, the former diminish. The large mononuclears apparently multiply at the expense of the small mononuclears or lymphocytes. It should he added, however, that a great excess of large mononuclear cells remain unaccounted for in this way.

In every respect the transitional forms go hand in hand with the large mononuclears.

No change was ohserved in the eosinophiles hefore convulsions, nor immediately afterward; except perhaps a slight in crease. Several hours following they had a tendency to become less numerous.

Case XX.-W. B. R., aged forty-nine years, admitted MFarch, 1892. Had felt nervous and run down for a year before coming to the hospital. Could not grasp simple problems. Gradually lack of judgment came on, delusions of grandeur, hallucinations. Pupils equal, do not respond to light. Knee-jerks absent. Dementis became pronounced. Speech thick and gait ataxic.

December 28. Had three convulsions this morning, involving chiefly the right-side, with twitching of the eyelids, facial muscles, right arm and leg. Ten minutes after the last the blood was examined and the examination repeated at intervals for two days.

January 17. This morning had another apoplectic seizure, the convulsive twitching lasting for two hours. During all this time there was a clonic spasm of the muscles and partial paralysis.

18th Srrallows with difficulty. Only partially conscious. Pulse, respiration, and temperature rising.

19th. Rapidly failing. Temperature rising.

20th. Died at 8.40 A.s.

Autopsy. Leptomeningitis, granulations in ependyma, atrophy of the cortex, also a lobular consolidation in one lung, prohahly due to inhalation. 


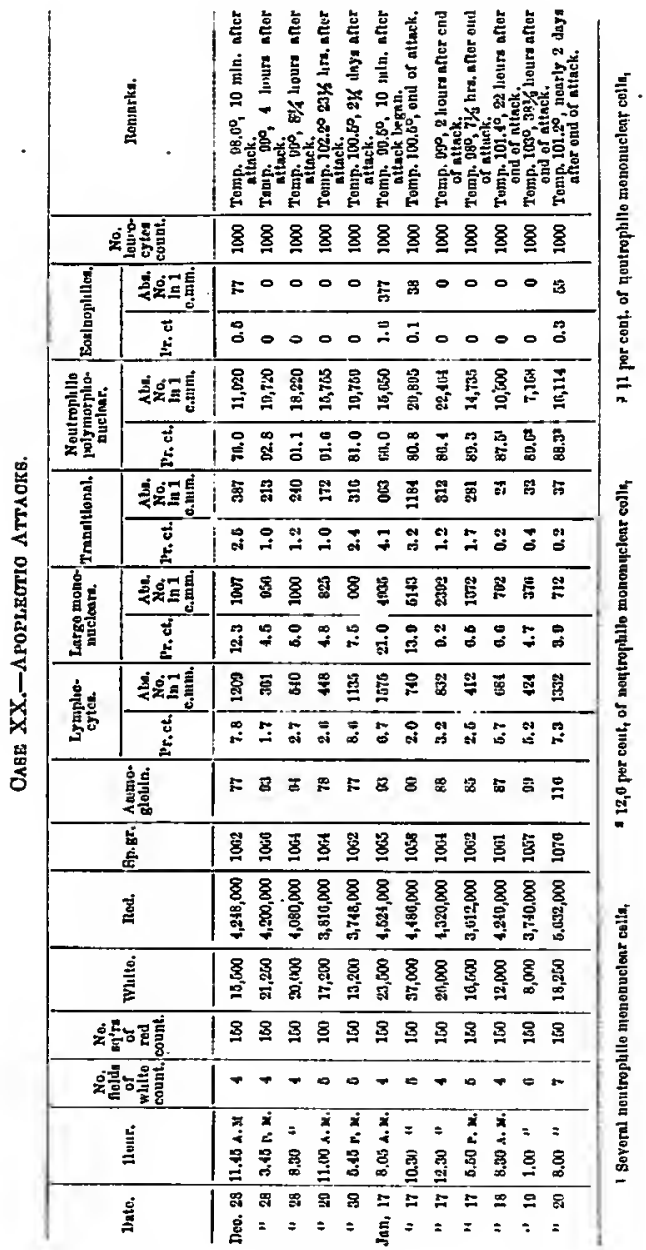


Both of these seizures were apoplectiform in nature, characterized hy muscular twitchings, partial paralysis, some temperature throughout, and prolonged unconsciousness. The first lasted over ten minutes, from

Chant III.

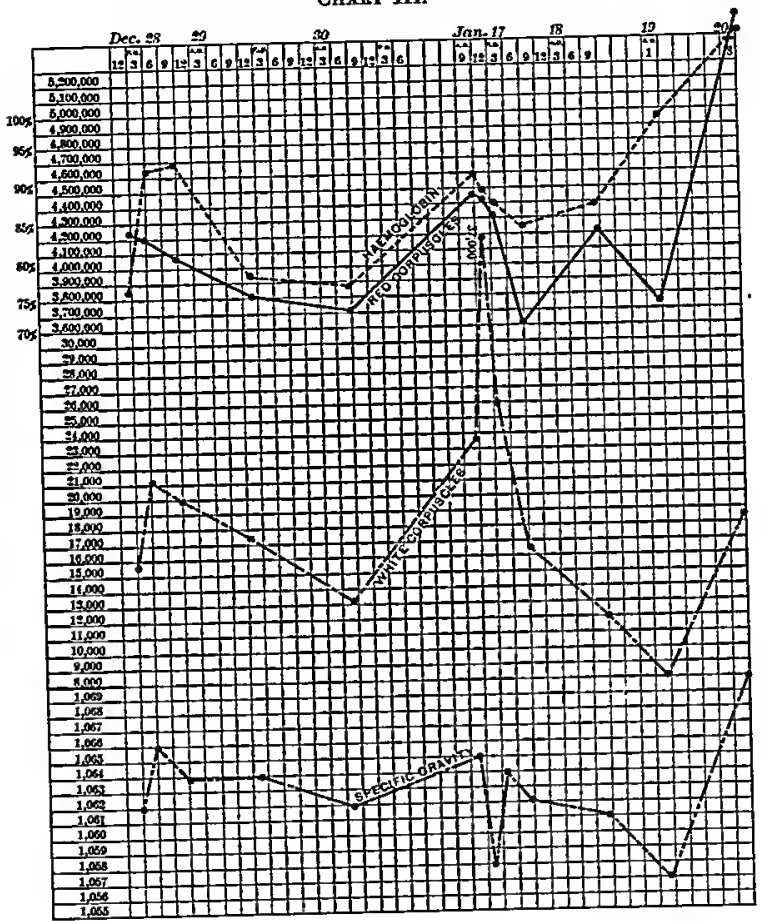

Showing the changes in the blood during and after two apoplectle attacks in general paralysis, Case XX.

the effects of which he was in bed two days with little temperatnre. The second attack continued for two hours, from which he never entirely recovered consciousness, and died. Unfortunately it was not posaihle to examine the hlood hefore the onset. But in the two-hour attack a 
with a view of getting light on the subject, Case I. was selected for the purpose, hecause his convulsive seizures were frequent and came with more regularity than is usuel. Not mnch difficulty was experienced in securing the hlood immediately after a seizure, hut it was quite different with the specimen preceding an attack, on eccount of the uncertainty of the onset. Since the ante-convulsive exeminetion is quite as important

\section{Chart II.}

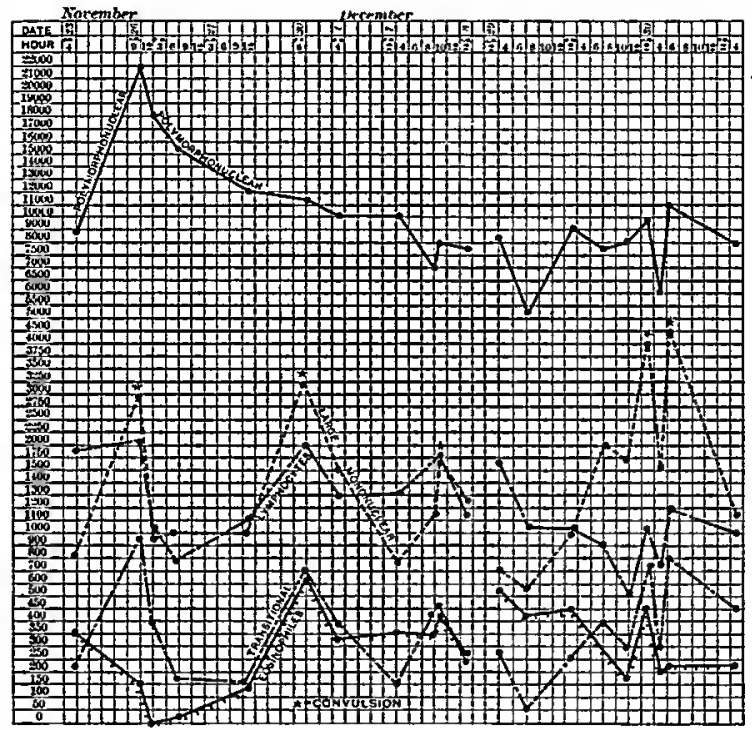

Showing the absolute number of the different varieles of lencocytes before and aner convolsons in case $L$

as the post-convulsive, en effort was made to learn the condition of the hlood just before the spasm as well as after. This was done in the following manner: heginning ot o time when on ettack was expected, examinetions were made continnously at ehont four hour intervels until it occurred. Thus the hlood was secored three hours hefore Convulsion IV. and one hour hefore Convulsion V. We were fortunete in getting a specimen only twenty-five minntes previons to Convulsion III. 
specimen was ohtained at the heginning and at the end, thus throwing some light on changes occurring during the seizure.

Both attacks were followed hy a diminution in the red corpuscles that did not soon disappear.

The hrmoglohin sustained only a slight reduction during the long attack, which tended to continne for some time afterward.

The epecific gravity fell dnring the progress of the attack and later rose again.

In contradistinction from this general lowering of blood-values, the white corpusoles were enormously augmented during the attack. In one instance the leucocytosis hegran to fall immediately after the seizure, and gradually disappeared; whereas in the other the maximum was not reached until four hours after the spasm had ceased. The highest count was obtained at the termination of the more severe attack, when it amounted to 37,000 .

The temperature cannot he considered as a factor in leucocytosis. It has heen shown hy Carter, ${ }^{1}$ Winternitz, and others that fever in itself will not produce leucocytosis. Moreover, in this case no correepondence rhatever exists hetween the height of the temperature and the degree of leucocytosig, since the lowest count was present at the time of the highest fever. The influence of the inbalation-pneumonin, which was most likely contracted a short time hefore death, cannot be held responsible for the leucocytosis, as will he shown in the discussion of the differential count.

At the last examination, thirty minutes hefore death, it will he observed that the red and white corpuseles, specific gravity, and heemoglohin all attrined an unusual height. The face was cyanosed, breathing difficult and stertorous, and the whole appearance that of a dying man. This increase in white cells has been described by Rieder and Litten ${ }^{3}$ under the name of "premortal" or "agonal" leucocytosis. They found it fairly congtant and dependent in its intensity upon the duration of the agony.

The polymorphonuclear cells were almost douhled in numher during the prolonged attack, while euhsequently they either fell gradually or attained a maximum a fer hours later and then diminished.

The lymphocytes were euhnormal at the heginning of the attack and fell atill lower at its termination, notwithstanding the leucocytosis was greater. Their number underwent even further depletion in the hours following, the ahsolute count heing only one-third to one-quarter of the normal. Restoration to the normal took place more slowly in the lymphocytes than in any other element.

I Dnirersity Iredical Jagazine, December, 1894, p. 159.

2 Loc cik p. 104. "Zur Pathologle des Blutes" Berlin. klln. Wochens., 1893, p. 27. 
The influence of the long attack on the eosinophiles was to reduce their namber exceedingly, while in slides taken several hours afterward none at all were present.

When the seiznre had just begun there was a decided increase in the large mononuclears, which became even greater at its termination, amounting to oper 5000 in a c.mm. in one instance. The retarn to the normol was comparatively rapid. What has heen said of the large mononuclear is true also of the transitional cells.

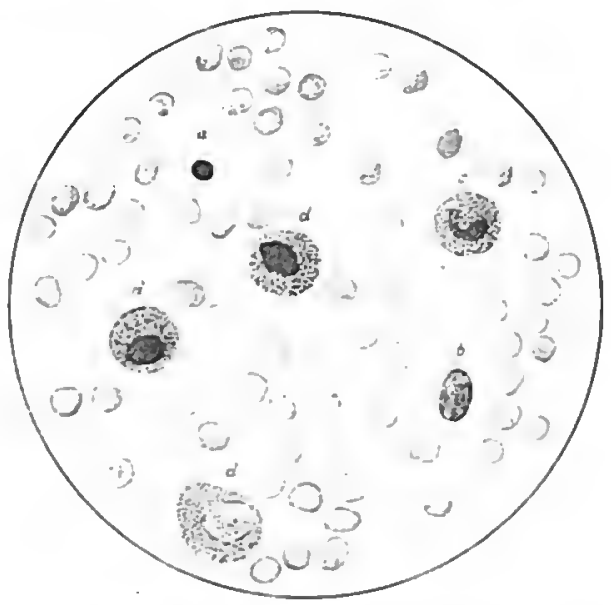

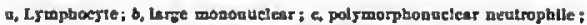
d, mosoneclear neutrophlle.

A striking feature of the stained preparations ras the variation in the chnracter of the large mononaclear cells at different times. Soon after an attsck cello with a small, round, deeply atsining nucleus like that of a lyophocyte, but with a large body of clear protoplasm, predominnted. Several hours later larger cells with irregular, faintly staining nuclei, that al most filled the cell-body, made up the prevailing type.

More particularly do we wish to call attention to a variety of cell that was present in this patient alone, namely, a cell as large or larger 
than the polymorphonuclear neutrophile, with a round or ovoid nucleus, deeply stained, and having a protoplasm thickly sprinkled with neutrophilic granules. These neutrophile mononuclear cells first appeared twenty-two hours nfter the last prolonged attack and forty-eight hours hefore death, hut only a few were found at this time. At the next examination, thirty-one and one-half hours hefore death, they constituted 12.6 per cent. of the total number of leucocytes, although those cells having much irregularity or a distinct indentation of the nucleus, were not included in this class. The ahsolute number in $\mathrm{n} \mathrm{c.mm.}$ was 1008. Finally, in the last specimen, ohtained thirty minutes hefore death, the total numher reached 2000 in a leucocytosis of 18,250 .

The origin and nature of these cells are somewhat ohscure. They certainly come under the definition of myelocytes, since granulations are as distinct and as ahundant in them as in the polymorphonuclear neutrophiles, hut it does not follow that they arise from the honemarrow.

A much simpler explanation presents itself. It is now quite commonly accepted as probahle, if not proved, that all the varieties of the leucocytes, excepting, perhaps, the eosinophiles, are hut different forms in the growth of the leucocytes. As Ouskow claims, it is likely that the lymphocyto is the youngest cell, and that hy the growth of its nucleus and protoplasm it hecomes a large mononuclear; this, in turn, hy a change in the shape of its nucleus and hy a granulation of the protoplasm, passes through the transitional form into the polymorphonuclear neutrophile cell. Physiologically in the evolution of the large mononuclear into the polymorphonuclear neutrophile the nucleus becomes irregular and polymorphous before the granulation is well marked. Now in this specimen (see illustration) every stage of this nuclear change can he followed from the perfectly round or ovoid or slightly indented forms to the typical horseshoe nucleus, in all of which the granules are equally distinct and numeroos. Why, then, is it not easier to explain these unusual forms hy supposing that the granulation, process has preceded the changes in the nucleus instead of appearing suhsequently?

These cells might have heen due to the apoplectic nttack itself or to the influeoce of the death-agony. If the former were true, we should expect that such cells would have heen found in his first attack, which was not the case. We hnve heen ahle to get a stained specimen in one other case three hours prior to death, hut no ahnormal leucocytes were present. It should he ndded, however, that the cyanosis and dyspnoea so pronounced in Case XX. were absent in this patient. The cause for the presence of these cells cannot he assigned. 


\section{General Conclubions.}

Geseral Paralyats. 1. The hremoglohin and red corpuscles are always diminished.

2. The specific gravity falls slightly helow the normal.

3. Most cases show a slight leucocytosis, amounting on an average to ahout 22 per cent. ahove the norral. Early cases may have no leucocytosis whatever.

4. In the differential count a decresse is found in the lymphocytes along with a marked increase in the large mononuclear cells. The eosinophiles in a few cases are very numerous.

Convulsions and Apoplectifonu Amacks. 1. The red corpuscles and hamoglobin are usually increased at the time of a convulsion. During an apoplectic attack of long duration they are hoth somewhat diminished.

2. The apecific gravity is variahle, sometimes increasing, sometimes diminishing, at the time of an attack.

3. There is a leucocytosis after convulsions and apoplectic attacks which is as audden as it is neually pronounced. It certainly does not appear until within a very ahort time preceding the convulsion, probably not before it actually takes place.

4. The degree of leucocytoais and the period of its continuance, as a rule, vary directly with the length and eeverity of the attack.

5. In the production of the leucocytosis the large mononuclear cella are increased relntively more than any other variety.

6. The fnct that after convulsions and ppoplectic nttacks in general paralysis there is not only an increzse in the number of white cells, but a change in their charncter, as shown hy the differentinl count, nnd nt times abnormal cells nppear, is an argument ngainst the theory that leucocytosis is merely a change in the distrihution of the white corpuscles.

I wish to take this opportnnity of thanking Dr. Cowles and Dr. Hoch for their assistance, and especially to acknowledge my indehtedness to Dr. Hibhard for aid in the bibliography. 